\title{
The Resistance of Soybean Genotypes to The Pod Feeding Insects
}

\author{
DOI: $10.18196 /$ pt.2019.093.48-57
}

\author{
Ayda Krisnawati*, Mochammad Muchlish Adie \\ Indonesian Legumes and Tuber Crops Research Institute, Jl. Raya Kendalpayak km 8 Malang 65101, East Java, Indonesia \\ *Corresponding author, email: my_ayda@yahoo.com
}

\begin{abstract}
One of the constraints impeding soybean production in the tropics is yield losses due to the damage by pod feeding insects. The research objective was to identify the resistance of soybean genotypes to the pod feeders. The existence of the pod feeding insects was evaluated on 24 soybean genotypes planted in Ngawi (Indonesia) in 2016. The experiment was arranged in a randomized block design with two environmental conditions. The first environmental condition was plants controlled by insecticide during plant growth, and the second condition was plants controlled by insecticide only up to 45 days after planting (dap). The pod feeding insects included pod sucking bug (Riptortus linearis), pod borer (Etiella zinckenella), and podworm (Helicoverpa sp.). The damage intensity of pod sucking bug at 45 dap of controlled environment reached 60.24\%, mean while the damage intensity of pod borer and podworm were 46.08\% and 3.85\%, respectively. This indicates that the natural population of pod sucking bug is relatively high and dominant. Of 24 soybean genotypes tested, NSP-16-2-8 was consistently resistant on environments with and without insecticide application, whereas NSP-16-1-4 was consistently resistant to the pod borer attack. Those genotypes were potential to be used as source of genes for pod feeding insects' resistance in the breeding program.

Keywords: Etiella zinckenella, Helicoverpa sp., Riptortus linearis, soybean
\end{abstract}

\section{ABSTRAK}

Salah satu masalah budidaya kedelai di daerah tropis adalah tekanan berbagai kompleks hama perusak polong. Tujuan penelitian adalah untuk mengidentifikasi ketahanan genotipe kedelai terhadap hama perusak polong. Eksistensi dari kompleks hama perusak polong diuji pada 24 genotipe kedelai yang dilakukan di Ngawi (Indonesia) pada tahun 2016. Penelitian dilaksanakan dengan menggunakan rancangan acak kelompok dengan dua lingkungan. Lingkungan pertama adalah tanaman dikendalian dengan insektisida selama pertumbuhan dan lingkungan kedua adalah hanya dikendalikan dengan insektisida sampai umur 45 hst. Hama perusak polong dominan terdiri dari hama pengisap polong (R. linearis), penggerek polong (E. zinckenella), dan pemakan polong (H. armigera). Pada lingkungan yang dikendalikan hingga 45 hst, intensitas serangan hama pengisap polong mencapai 60,24\%, penggerek polong 46,08\% dan hama pemakan polong hanya sebesar 3,85\%; mengindikasikan bahwa populasi alam hama pengisap polong cukup tinggi dan dominan. Dari 24 genotipe kedelai yang diuji, teridentifikasi genotipe kedelai NSP-16-2-8 konsisten bereaksi tahan pada lingkungan dengan dan tanpa pengendalian dengan insektisida, sedangkan genotipe NSP-16-1-4 tergolong tahan terhadap hama penggerek polong. Kedua genotipe tersebut berpotensi digunakan sebagai sumber ketahanan terhadap hama perusak polong.

Kata Kunci: Etiella zinckenella, Helicoverpa sp., Riptortus linearis, soybean

\section{INTRODUCTION}

The infestation of pest complexes is one of the major problems in the soybean cultivation in the tropics. There are three destructive pod feeding insects that potentially decrease soybean production in Indonesia, namely pod sucking bug, pod borer, and pod worm. The magnitude of the soybean yields losses due to the pod feeding insects was between 20 - 100\% (Jones and Sullivan, 1978; Singh and Allen, 1980; Prayogo and Suharsono, 2005; Bayu, 2015) depending on the level of plant resistance and soybean growth phase (Asadi et al., 2012). So far, soybean varieties that are relatively resistant to each pod feeding insects are not available yet, hence, the main pest control is still using both of chemical and botanical insecticides (Mustikarini et al., 2014; Hendrival et al., 2013; Anshori and Prasetiono, 2016; Sumartini, 2016).

Based on the type of the attack, there are two groups of soybean pod feeders, i.e. pod borer (E. zinckenella, H. armigera) and podworm (Riptortus sp, N. viridula, and Piezodorus hybneri). The pod feeding insects may attack soybeans either individually or simultaneously, especially on soybean crops during the dry season of June/July - September/October as the largest soybean growing season in Indonesia. Lourencao et al. (2002) had identified stink bug complex as the most economically destructive pest on soybean which consisted of N. viridula, Piezodorus 
guildinii and Euchistus heros. In Bangladesh, it was reported that pod sucking bug, Riptortus pedestris (Fabricius) \& Halyomorpha halys (Stal), had become the main pod feeding pests on soybean (Rahman and Lim, 2017). In South Sulawesi (Indonesia), Rahayu et al. (2018) found three types of destructive insect as pod sucking pests ( $N$. viridula, $R$. linearis, and Leptocorisa acuta) and a type of pod borer pest (E. zinckenella). The yield losses due to infestation of pod feeders do not only reduce the productivity per unit area, but also decrease the seed vigor (Bae et al., 2014) as a result of imperfect seed formation or due to seed physical damage.

Pest resistant variety is an important component of integrated pest management (Bazok et al., 2011; Pretty and Bharucha, 2015). Development of soybean variety tolerant to pod feeders requires the availability of resistance genes sources, appropriate selection methods, and understanding of the determinants of pest resistance (Krisnawati et al., 2016; Johnson et al., 2017). The use pest resistant varieties are not only able to minimize the yield losses but also have positive implications on the development of environmentally friendly conditions (Pinheiro et al., 2005).

The most sensitive stage of soybean growth to pod-sucking bug infestation is between the reproductive phases R3 - R5 (Acle and Rolim, 1994). Other studies have reported that Hemipterans pests group prefer young pods, tender growth, and developing seeds or when the reproductive growth of soybeans is in the phase of R4 - R6 (Bundy and McPherson, 2000). In stink bug pests, the peak of infestation is during the mid to late pod filling stage (stages R5-R7) (Baur et al., 2000). Rahman and Lim (2017) compared the effects of two pod sucking bugs on their behavioral, and they reported that $R$. pedestris prefers seeds over pods, while $H$. halys prefers pods over seeds. The effect of two species of pod-sucking bugs on soybean showed that $72 \%$ of pod damage was caused by Riptortus destipes which was higher compared with 44\% pod damage by $N$. viridula (Acle and Rolim, 1994).

Dzemo et al. (2010) evaluated the resistance of three cowpea varieties to pod sucking bug Clavigralla tomentosicollis and found differences in the pre oviposition period, ovoposition period, and number of eggs among the three tested varieties. Research on the pod sucking bug C. tomentosicollis in cowpea (Vigna unguiculata) revealed that the longer growth development of the nymph was showed in resistant variety than those in susceptible variety. This reveals the variability of interactions between varieties and different pests. In Brazil, it was reported that the soybean genotype IAC 100 was categorized as resistant and the BRS Silvania RR was included to susceptible to the brown stink bug E. heros (Timbo et al., 2014). Furthermore, de Godoi and Pinheiro (2009) stated that the character of percentage index of pod damage can be recommended as a resistant selection criteria for pod-attacking stink bugs in the initial generation (F3 or F4) population, whereas selection criteria for advanced population were suggested using character of the grain filling period and percentage of spotted seeds.

In Indonesia, research on the damage intensity caused by the pod sucking bug ( $R$. linearis), pod borer (E. zinckenella) and podworm (H. armigera) as well as soybean resistance to those three destructive pod feeding insects has never been reported. The results of this study will be important in order to obtain resistant genotypes which will be used in the breeding program. Therefore, the research objective was to identify the resistance of soybean genotypes to each pod feeder.

\section{MATERIALS AND METHODS}

Sample Preparation and Experimental Design

The study was conducted in Ngawi (East Java, Indonesia) during the dry season in 2016. The research site was located at SL $7.4095^{\circ}$ and EL 
$111.3726^{\circ}$ with the climate type of C3 (Oldeman, by insecticide from planting time to harvest. The 1974), elevation of $50 \mathrm{~m}$ above sea level, tempera- treatment consisted of 24 soybean genotypes with ture of $24^{\circ}-33^{\circ} \mathrm{C}$, and relative humidity of $87.5 \%$. five replications. The research was conducted in

The research was arranged in a randomized wetland after rice cultivation under zero-tillage block design consisting of two environmental condition. Each genotype was planted in a $1.2 \mathrm{~m} \times$ conditions. The first environmental condition $4.5 \mathrm{~m}$ plot size, plant spacing of $40 \mathrm{~cm} \times 15 \mathrm{~cm}$, and (selected protection/ISP) was soybean plants two plants per hill. Pest and disease were controlled controlled by insecticide only up to 45 days after optimally. Plant was fertilized by $250 \mathrm{~kg}$ Phonska planting, and the second environmental condition and $100 \mathrm{~kg}$ SP36 which was done after planting. (full protection/IFP) was soybean plants controlled

Table 1. The pod damage intensity caused by pod sucking bug, pod borer, and podworm of 24 soybean genotypes

\begin{tabular}{|c|c|c|c|c|c|c|c|c|c|c|}
\hline \multirow[t]{3}{*}{ No } & \multirow[t]{3}{*}{ Genotype } & \multicolumn{9}{|c|}{ Pod damage intensity (\%) } \\
\hline & & \multicolumn{3}{|c|}{ R. linearis } & \multicolumn{3}{|c|}{ E. zinckenella } & \multicolumn{3}{|c|}{ H. armigera } \\
\hline & & IFPa & $\mathrm{ISPb}$ & Avg $^{c}$ & IFPa & ISPb & $\operatorname{Avg}^{c}$ & IFPa & ISPb & $\operatorname{Avg}^{c}$ \\
\hline 1 & NSP-16-2-13 & 36.05 (MR) & 56.60 (MR) & 46.32 & $15.04(S)$ & 38.92 (MR) & 26.98 & 1.60 (MR) & $2.44(\mathrm{R})$ & 2.02 \\
\hline 2 & NSP-16-1-1 & 37.65 (MR) & $67.74(S)$ & 52.70 & $5.62(\mathrm{R})$ & $34.65(R)$ & 20.14 & $0.53(\mathrm{HR})$ & $0.98(\mathrm{R})$ & 0.76 \\
\hline 3 & NSP-16-30-7 & 40.71 (MR) & $63.10(S)$ & 51.90 & 9.09 (MR) & $52.61(S)$ & 30.85 & $3.70(S)$ & $1.57(\mathrm{R})$ & 2.63 \\
\hline 4 & NSP-16-4-4 & 41.13 (MR) & $66.92(S)$ & 54.03 & $15.01(S)$ & $47.46(S)$ & 31.24 & $4.04(S)$ & $2.01(\mathrm{R})$ & 3.03 \\
\hline 5 & NSP-16-16-2 & $68.40(\mathrm{HS})$ & 56.08 (MR) & 62.24 & $8.48(\mathrm{R})$ & 43.51 (MR) & 25.99 & 1.58 (MR) & 2.95 (MR) & 2.26 \\
\hline 6 & NSP-16-3-3 & 33.89 (MR) & $60.53(S)$ & 47.21 & $15.68(S)$ & 40.93 (MR) & 28.30 & $2.75(S)$ & $1.82(\mathrm{R})$ & 2.29 \\
\hline 7 & NSP-16-6-13 & $45.84(S)$ & $65.70(S)$ & 55.77 & $12.97(S)$ & 37.98 (MR) & 25.48 & $4.02(S)$ & $0.77(\mathrm{R})$ & 2.39 \\
\hline 8 & NSP-16-1-2 & 37.25 (MR) & 58.75 (MR) & 48.00 & $14.78(S)$ & 37.80 (MR) & 26.29 & $2.89(S)$ & $1.85(\mathrm{R})$ & 2.37 \\
\hline 9 & NSP-16-5-5 & 35.59 (MR) & 52.06 (MR) & 43.83 & $16.32(S)$ & 35.59 (MR) & 25.95 & $0.71(\mathrm{R})$ & $7.78(\mathrm{~S})$ & 4.25 \\
\hline 10 & NSP-16-6-11 & 40.92 (MR) & 56.30 (MR) & 48.61 & 10.29 (MR) & $47.28(S)$ & 28.79 & 2.48 (MR) & $0.48(\mathrm{R})$ & 1.48 \\
\hline 11 & NSP-16-8-1 & 38.84 (MR) & 55.24 (MR) & 47.04 & 9.52 (MR) & 38.63 (MR) & 24.08 & $0.89(R)$ & $0.95(\mathrm{R})$ & 0.92 \\
\hline 12 & NSP-16-1-3 & 33.48 (MR) & $39.25(\mathrm{R})$ & 36.36 & $14.71(S)$ & 67.59 (HS) & 41.15 & $3.66(S)$ & $2.71(\mathrm{R})$ & 3.19 \\
\hline 13 & NSP-16-6-12 & $44.15(S)$ & $99.80(\mathrm{HS})$ & 71.98 & 11.76 (MR) & 65.34 (HS) & 38.55 & 1.31 (MR) & 2.96 (MR) & 2.13 \\
\hline 14 & NSP-16-6-8 & 35.09 (MR) & $69.44(S)$ & 52.27 & 9.30 (MR) & 35.20 (MR) & 22.25 & 1.05 (MR) & $3.75(\mathrm{~S})$ & 2.40 \\
\hline 15 & NSP-16-2-8 & $31.81(R)$ & 34.46 (HR) & 33.14 & $15.81(S)$ & $54.55(S)$ & 35.18 & $3.97(S)$ & $18.02(\mathrm{HS})$ & 11.00 \\
\hline 16 & NSP-16-12-15 & $45.13(S)$ & 48.24 (MR) & 46.69 & $13.55(S)$ & 65.59 (HS) & 39.57 & $3.27(S)$ & $13.13(\mathrm{HS})$ & 8.20 \\
\hline 17 & NSP-16-6-3 & 41.07 (MR) & 48.40 (MR) & 44.74 & $6.31(\mathrm{R})$ & 38.51 (MR) & 22.41 & $0.13(\mathrm{HR})$ & 8.40 (HS) & 4.27 \\
\hline 18 & NSP-16-19-7 & 39.21 (MR) & $68.85(S)$ & 54.03 & 24.20 (HS) & 63.99 (HS) & 44.10 & 7.13 (HS) & $2.04(\mathrm{R})$ & 4.59 \\
\hline 19 & NSP-16-1-7 & $47.89(S)$ & $68.35(S)$ & 58.12 & 12.24 (MR) & 38.81 (MR) & 25.53 & 2.15 (MR) & $2.48(\mathrm{R})$ & 2.32 \\
\hline 20 & NSP-16-6-7 & $44.71(S)$ & 58.31 (MR) & 51.51 & $12.84(S)$ & 43.65 (MR) & 28.24 & $3.76(S)$ & 3.63 (MR) & 3.69 \\
\hline 21 & NSP-16-1-4 & $49.67(S)$ & 58.38 (MR) & 54.03 & 12.50 (MR) & $31.12(\mathrm{R})$ & 21.81 & 1.39 (MR) & $4.27(S)$ & 2.83 \\
\hline 22 & Grobogan & $32.11(\mathrm{R})$ & $62.78(S)$ & 47.44 & 10.42 (MR) & $59.41(\mathrm{HS})$ & 34.91 & 2.61 (MR) & $0.92(\mathrm{R})$ & 1.77 \\
\hline 23 & Anjasmoro & $59.87(\mathrm{HS})$ & $76.82(\mathrm{HS})$ & 68.35 & 10.92 (MR) & 35.85 (MR) & 23.38 & 1.52 (MR) & $0.86(\mathrm{R})$ & 1.19 \\
\hline \multirow[t]{3}{*}{24} & Argomulyo & 34.43 (MR) & 51.65 (MR) & 43.04 & $19.36(\mathrm{HS})$ & $50.98(S)$ & 35.17 & 5.80 (HS) & $5.19(\mathrm{~S})$ & 5.49 \\
\hline & Average & $41.45(\mathrm{~S})$ & $60.16(S)$ & 50.81 & $12.78(S)$ & $46.08(S)$ & 29.43 & 2.62 (MR) & 3.83 (MR) & 3.23 \\
\hline & Standard deviation & 8.48 & 12.62 & 8.56 & 4.01 & 11.05 & 6.53 & 1.67 & 4.12 & 2.27 \\
\hline
\end{tabular}

HS (Highly Susceptible), S (Susceptible), MR (Moderately Resistant), R (Resistant), HR (Highly Resistant)

afull controlled by insecticide from planting time to harvest

${ }^{b}$ controlled by insecticide until 45 dap

caverage damage intensity of IFP and ISP 
Table 2. The seed damage intensity caused by pod sucking bug, pod borer, and podworm of 24 soybean genotypes

\begin{tabular}{|c|c|c|c|c|c|c|c|c|c|c|}
\hline \multirow[t]{3}{*}{ No } & \multirow[t]{3}{*}{ Genotype } & \multicolumn{9}{|c|}{ Seed damage intensity (\%) } \\
\hline & & \multicolumn{3}{|c|}{ R. linearis } & \multicolumn{3}{|c|}{ E. zinckenella } & \multicolumn{3}{|c|}{ H. armigera } \\
\hline & & IFPa & $\mathrm{ISPb}$ & $\operatorname{Avg}^{c}$ & IFPa & $I S P^{b}$ & $\operatorname{Avg}^{c}$ & IFPa & $\mathrm{ISPb}$ & $\operatorname{Avg}^{c}$ \\
\hline 1 & NSP-16-2-13 & 15.58 (MR) & $51.00(\mathrm{HS})$ & 33.29 & $11.78(S)$ & $31.40(S)$ & 21.59 & 0.38 (HS) & $0.00(\mathrm{R})$ & 0.19 \\
\hline 2 & NSP-16-1-1 & 20.40 (MR) & $51.69(\mathrm{~S})$ & 36.05 & 8.31 (MR) & 29.80 (MR) & 19.06 & 0.16 (MR) & 0.09 (MR) & 0.12 \\
\hline 3 & NSP-16-30-7 & 16.89 (MR) & 40.72 (MR) & 28.80 & 6.12 (MR) & 38.28 (HS) & 22.20 & $0.00(R)$ & $0.00(\mathrm{R})$ & 0.00 \\
\hline 4 & NSP-16-4-4 & 18.31 (MR) & $62.41(\mathrm{HS})$ & 40.36 & $9.80(S)$ & 29.80 (MR) & 19.80 & $0.84(\mathrm{HS})$ & $0.00(\mathrm{R})$ & 0.42 \\
\hline 5 & NSP-16-16-2 & 58.29 (HS) & $46.85(S)$ & 52.57 & $5.08(R)$ & $44.02(\mathrm{HS})$ & 24.55 & $0.00(R)$ & $0.00(\mathrm{R})$ & 0.00 \\
\hline 6 & NSP-16-3-3 & 15.76 (MR) & $31.63(\mathrm{R})$ & 23.69 & 7.31 (MR) & 26.26 (MR) & 16.79 & $0.00(\mathrm{R})$ & $0.00(\mathrm{R})$ & 0.00 \\
\hline 7 & NSP-16-6-13 & $24.41(S)$ & $45.92(S)$ & 35.17 & $9.72(S)$ & $23.08(R)$ & 16.40 & $0.35(\mathrm{HS})$ & $0.00(\mathrm{R})$ & 0.17 \\
\hline 8 & NSP-16-1-2 & 20.78 (MR) & 37.11 (MR) & 28.95 & 8.04 (MR) & 27.71 (MR) & 17.87 & $0.20(S)$ & $0.00(\mathrm{R})$ & 0.10 \\
\hline 9 & NSP-16-5-5 & 19.59 (MR) & 41.70 (MR) & 30.64 & $9.87(S)$ & $23.06(R)$ & 16.47 & $0.00(R)$ & $2.91(\mathrm{HS})$ & 1.46 \\
\hline 10 & NSP-16-6-11 & 18.28 (MR) & $43.59(\mathrm{~S})$ & 30.94 & 7.19 (MR) & 25.04 (MR) & 16.12 & 0.16 (MR) & $0.00(\mathrm{R})$ & 0.08 \\
\hline 11 & NSP-16-8-1 & $23.70(S)$ & 42.20 (MR) & 32.95 & 5.96 (MR) & 24.35 (MR) & 15.15 & 0.07 (MR) & $0.00(\mathrm{R})$ & 0.03 \\
\hline 12 & NSP-16-1-3 & $27.36(S)$ & $44.62(S)$ & 35.99 & $13.83(\mathrm{HS})$ & 39.97 (HS) & 26.90 & 0.55 (HS) & $0.00(\mathrm{R})$ & 0.28 \\
\hline 13 & NSP-16-6-12 & $24.36(S)$ & 37.25 (MR) & 30.81 & $14.52(\mathrm{HS})$ & $32.76(S)$ & 23.64 & $0.00(R)$ & 0.03 (MR) & 0.01 \\
\hline 14 & NSP-16-6-8 & 16.51 (MR) & $52.09(\mathrm{HS})$ & 34.30 & $4.92(\mathrm{R})$ & 25.72 (MR) & 15.32 & 0.10 (MR) & $0.00(\mathrm{R})$ & 0.05 \\
\hline 15 & NSP-16-2-8 & $11.48(\mathrm{R})$ & $24.58(\mathrm{HR})$ & 18.03 & $13.23(S)$ & $34.74(S)$ & 23.99 & 0.59 (HS) & 2.48 (HS) & 1.54 \\
\hline 16 & NSP-16-12-15 & $22.98(\mathrm{~S})$ & $48.47(\mathrm{~S})$ & 35.72 & $10.14(\mathrm{~S})$ & $33.28(\mathrm{~S})$ & 21.71 & $0.03(R)$ & $0.00(R)$ & 0.01 \\
\hline 17 & NSP-16-6-3 & 19.84 (MR) & $44.06(S)$ & 31.95 & $4.65(R)$ & 28.04 (MR) & 16.34 & $0.00(R)$ & 0.16 (MR) & 0.08 \\
\hline 18 & NSP-16-19-7 & 14.55 (MR) & $31.93(R)$ & 23.24 & 17.57 (HS) & $37.48(\mathrm{HS})$ & 27.52 & $0.24(S)$ & $0.00(\mathrm{R})$ & 0.12 \\
\hline 19 & NSP-16-1-7 & $27.60(S)$ & $44.90(S)$ & 36.25 & 8.70 (MR) & 35.30 (HS) & 22.00 & $0.13(\mathrm{MR})$ & $0.00(\mathrm{R})$ & 0.06 \\
\hline 20 & NSP-16-6-7 & $24.85(S)$ & $44.91(S)$ & 34.88 & 20.14 (HS) & 27.38 (MR) & 23.76 & 0.14 (MR) & $0.00(\mathrm{R})$ & 0.07 \\
\hline 21 & NSP-16-1-4 & $27.13(S)$ & $51.39(\mathrm{~S})$ & 39.26 & 7.35 (MR) & $19.84(\mathrm{R})$ & 13.59 & $0.00(R)$ & $0.00(\mathrm{R})$ & 0.00 \\
\hline 22 & Grobogan & 15.59 (MR) & $31.39(\mathrm{R})$ & 23.49 & 6.31 (MR) & $35.85(S)$ & 21.08 & $0.19(S)$ & $0.00(\mathrm{R})$ & 0.10 \\
\hline 23 & Anjasmoro & $41.72(\mathrm{HS})$ & $55.50(\mathrm{HS})$ & 48.61 & 7.39 (MR) & $19.31(R)$ & 13.35 & $0.00(R)$ & $0.00(\mathrm{R})$ & 0.00 \\
\hline \multirow[t]{3}{*}{24} & Argomulyo & 15.68 (MR) & $30.16(\mathrm{R})$ & 22.92 & $12.15(S)$ & $36.08(S)$ & 24.11 & 0.12 (MR) & $0.00(\mathrm{R})$ & 0.06 \\
\hline & Average & $22.57(S)$ & 43.17 (MR) & 32.87 & $9.59(\mathrm{~S})$ & $30.36(S)$ & 19.97 & 0.18 (MR) & 0.24 (MR) & 0.21 \\
\hline & Standard deviation & 9.65 & 8.79 & 7.67 & 3.93 & 6.38 & 4.09 & 0.22 & 0.75 & 0.40 \\
\hline
\end{tabular}

HS (Highly Susceptible), S (Susceptible), MR (Moderately Resistant), R (Resistant), HR (Highly Resistant)

afull controlled by insecticide from planting time to harvest

${ }^{b}$ controlled by insecticide until 45 dap

caverage damage intensity of IFP and ISP

\section{Data collection and analysis}

The damage intensity of pod sucking bug $(R$. linearis), pod borer (E. zinckenella) and podworm (H. armigera) was observed based on five random sample plants. Observations consisted of the number of total pods, number of total seeds, the number of pods and seeds attacked by pod sucking bug, pod borer, and podworm. Observations on the agronomic characters were made on the days to flowering and weight of 100 seeds.
The damages intensity was calculated based on the following formula:

$$
\begin{aligned}
& \text { Pod damage }(\%)=\frac{\text { Number of pod damage }}{\text { Number of total pods }} \times 100 \% \\
& \text { Seed damage }(\%)=\frac{\text { Number of seed damage }}{\text { Number of total serds }} \times 100 \%
\end{aligned}
$$

The grouping of resistance follows a method by Chiang and Talekar (1980):

$$
\begin{array}{ll}
\mathrm{x}>\overline{\mathrm{x}}+2 \mathrm{SD} & =\text { HS (Highly Susceptible) } \\
\overline{\mathrm{x}}>\mathrm{x}>\overline{\mathrm{x}}+2 \mathrm{SD} & =\mathrm{S} \text { (Susceptible) }
\end{array}
$$




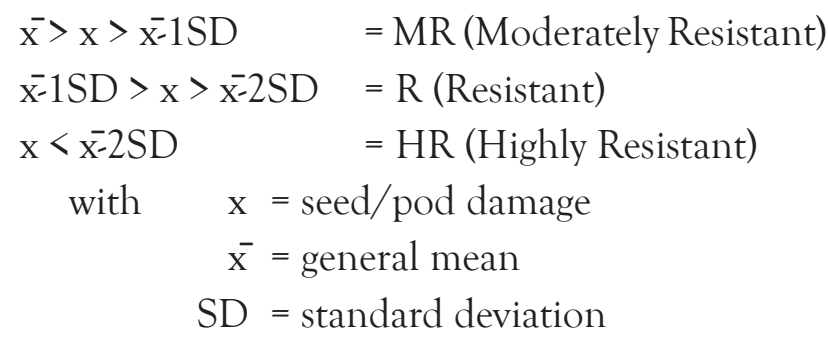

\section{RESULTS AND DISCUSSION}

In tropical regions, such as Indonesia, soybeans are planted throughout the season following the planting pattern in the paddy field of paddy-paddysoybean, and in the dry land of soybean-soybean. Soybean cultivation on paddy fields during the third cropping pattern (June/July-September/ October), is the largest soybean cultivation in Indonesia and it is also at the peak of the dry season, especially the growth phase of seed filling up to harvest period. The condition of those agro-ecosystem increases population of pod pest complex.

The soybean planting pattern at the research study was paddy - paddy - soybean. Soybean cultivation during the second dry season (July - October) is generally attacked by pod feeding insects which consisted of pod sucking bug ( $R$. linearis), pod borer (E. zinckenella) and podworm (H. armigera). In this study, the natural population of pod sucking pest and pod borer were very high, while that of the podworm was relatively low. This can be seen from the average intensity of pod damage by pod sucking bug on full control with insecticide (IFP) which reached $41.45 \%$, and with selective control of insecticide until 45 dap (ISP) reaching 60.16\%. Intensity of pod damage by pod sucking bug in IFP ranged from $31.81-68.40 \%$ and in ISP ranged from $34.46-99.80 \%$ (Table 1). The range of seed damage by pod sucking bug in IFP was from 11.48 - 58.29\% with an average of $22.57 \%$, and seed damage in the ISP was between $24.58-62.41 \%$ with an average of $43.17 \%$ (Table 2).

The range of pod damage intensity by pod borer in IFP was $5.62-24.20 \%$ with an average of $12.78 \%$, while in the ISP ranged from 31.12-67.59\% with an average of $46.08 \%$ (Table 1). The range of seed damage intensity by pod borer in the IFP ranged from $4.92-20.14 \%$ with an average of $9.59 \%$, and in the ISP ranged from $19.84-44.02 \%$ with an average of $30.36 \%$ (Table 2). The intensity of pod damage caused by pod worm in IFP and ISP were $2.62 \%$ and $3.83 \%$, respectively. Meanwhile, the seed damage was $0.18 \%$ in IFP and $0.24 \%$ in ISP (Table 1, Table 2). Among the three varieties tested (Anjasmoro, Argomulyo and Grobogan), Argomulyo variety showed higher resistance than the others.

The soybean yield losses by pod sucking bug was higher than those of caused by pod borer. The pod damage intensity by pod worm was relatively low. A higher population of pod sucking bug was because $R$. linearis is the most common species found in Indonesia which has wide distribution throughout the country (Prayogo and Suharsono, 2005; Asadi, 2012; Suharsono \& Sulistyowati, 2012). An alterna-

Table 3. The resistance criteria to pod feeding insects based on pod damage

\begin{tabular}{|c|c|c|c|c|c|c|}
\hline \multirow{2}{*}{ Criteria } & \multicolumn{2}{|c|}{$R$ linearis } & \multicolumn{2}{|c|}{ E. zinckenella } & \multicolumn{2}{|c|}{ H. armigera } \\
\hline & IFPa & ISPb & IFPa & $I S P^{b}$ & IFPa & ISPb \\
\hline$H^{c}$ & $<24.5$ & $<34.92$ & $<4.75$ & $<23.98$ & $<0.71$ & $<-.4 .40$ \\
\hline$R^{d}$ & $24.50-32.98$ & $34.92-47.54$ & $4.75-8.76$ & $23.98-35.03$ & $0.71-0.95$ & $-4.40-2.90$ \\
\hline MRe & $>32.98-41.45$ & $>47.54-60.16$ & $>8.76-12.78$ & $>35.03-46.08$ & $>0.95-2.62$ & $>2.90-3.83$ \\
\hline$S^{f}$ & $>41.45-49.93$ & $>60.16-72.77$ & $>12.78-16.79$ & $>46.08-57.13$ & $>2.62-4.29$ & $>3.83-7.95$ \\
\hline$H S^{g}$ & $>49.93$ & $>72.77$ & $>16.79$ & $>57.13$ & $>4.29$ & $>7.95$ \\
\hline
\end{tabular}

afull controlled by insecticide from planting time to harvest

${ }^{b}$ controlled by insecticide until 45 dap

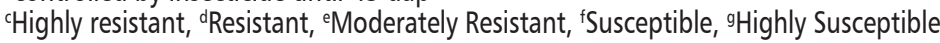


Table 4. The resistance criteria to pod feeding insects based on seed damage

\begin{tabular}{lcccccc}
\hline \multirow{2}{*}{ Criteria } & \multicolumn{2}{c}{ R linearis } & \multicolumn{2}{c}{ E. zinckenella } & \multicolumn{2}{c}{ H. armigera } \\
\cline { 2 - 7 } & \multicolumn{1}{c}{ IFPa } & ISPb & IFPa & ISPb & IFPa & ISPb \\
\hline $\mathrm{HR}^{\mathrm{c}}$ & $<3.27$ & $<25.58$ & $<1.73$ & $<17.59$ & $<-0.26$ & $<-1.16$ \\
$\mathrm{R}^{\mathrm{d}}$ & $3.27-12.92$ & $25.58-34.38$ & $1.73-5.66$ & $17.59-23.97$ & $-0.26-0.04$ & $-1.16-0.00$ \\
$\mathrm{MR}^{\mathrm{e}}$ & $>12.92-22.57$ & $>34.38-43.57$ & $>5.66-9.59$ & $>23.97-30.36$ & $>0.04-0.18$ & $>0.00-0.25$ \\
$\mathrm{~S}^{\dagger}$ & $>22.57-32.22$ & $>43.57-51.96$ & $>9.59-13.51$ & $>30.36-36.74$ & $>0.18-0.39$ & $>0.25-0.98$ \\
$\mathrm{HS}^{9}$ & $>32.22$ & $>51.86$ & $>13.51$ & $>36.74$ & $>0.39$ & $>0.98$ \\
\hline
\end{tabular}

afull controlled by insecticide from planting time to harvest

${ }^{\mathrm{b}}$ controlled by insecticide until 45 dap

CHighly resistant, ${ }^{\text {Resistant, }}{ }^{\circ}$ Moderately Resistant, ${ }^{\text {SSusceptible, }}{ }^{9}$ Highly Susceptible

tive way to minimize the yield losses caused by the pod sucking bug is by providing the high yielding soybean variety and in accordance with the users' preference in Indonesia.

This research result revealed that the major pod feeders on soybean during the dry season were pod sucking bug and pod borer, whereas pod worm was in relatively low population. In Brazil, de Godoi \& Pinheiro (2009) reported that pod sucking (stink) bug complex which consisted of $N$. viridula, $P$. guildinii, and E. heros were the most harmful pests on soybean. Those pests complex attack soybean during pod formation, filling and maturation (Gazzoni, 1998; Lourencao et al., 2002). Lucini et al. (2016) revealed that the stink bug P. guildinii was a major pest of soybean in America. In recent years, its abundance has increased in the southern United States and it has become the most important stink bug pest of soybean in southern Texas. In Indonesia, Asadi (2009) reported that the pod pests commonly found in Indonesia causing the yield losses were $R$. linearis $(\mathrm{F}), \mathrm{N}$. viridula $(\mathrm{L})$, and Piezodorus rubrofasciatus. Furthermore, among those three species, $R$. linearis caused the greatest loss in soybean yield, which the peak of its attack was during the growth phase of R5 - R6. Other studies (Prayogo and Suharsono, 2005; Naito, 2008) also reported that the most critical phase of $R$. linearis attack was started form pod filling period until maturity. R5 - R6 phase on soybean is characterized by green and soft pod and the seed is not fully formed. This means that the results of this study were consistent with the previous researches that the pod sucking becomes the most important pest that caused decrease in soybean yield production in Indonesia.

The intensity of pod damage caused by pod sucking and pod borer was higher than the intensity of seed damage. The interaction between insect and soybean genotype is random. Each insect pest will search for feed and, at early stages of food searching, will try all the existing soybean genotypes. Janz and Nylin (1997) suggest that the insect behavior in finding the right host is very important because it is used as the determination of its host range. Hence, there are five steps in the host selection process by herbivorous insects, i.e finding the host habitat, host-finding, host recognition, host acceptance and host suitability. These five steps make it possible to make one or more steps as a barrier for insects in determining their host (Mudjiono, 1998). Two factors that could be a barrier to the interaction between insect pests with soybean genotype are morphological and chemical characters existing in the pods. The morphological character of the pod will be the main barrier of any genotype to minimize the seed damage. Several researches showed that trichome character and pod wall thickness in soybean were expected to be determinant factors of soybean resistance to pod pests complexes (Traw and Dawson, 2002; Shepard and Wagner, 2007; Dabire-Binso et al., 2010). Suharsono and 
Table 5. The mapping of soybean resistance to pod feeding insects based on pod damage

\begin{tabular}{|c|c|c|c|c|c|c|}
\hline \multirow[t]{3}{*}{ Criteria } & \multicolumn{6}{|c|}{ Number of genotypes } \\
\hline & \multicolumn{2}{|c|}{$R$ linearis } & \multicolumn{2}{|c|}{ E. zinckenella } & \multicolumn{2}{|c|}{ H. armigera } \\
\hline & IFPa & ISPb & IFPa & $I S P^{b}$ & IFPa & $I S P^{b}$ \\
\hline$H R^{c}$ & 0 & 1 & 0 & 0 & 2 & 0 \\
\hline$R^{d}$ & 2 & 1 & 3 & 2 & 2 & 14 \\
\hline $\mathrm{MR}^{\mathrm{e}}$ & 14 & 11 & 9 & 12 & 9 & 3 \\
\hline$S^{f}$ & 6 & 9 & 10 & 5 & 9 & 4 \\
\hline HSg & 2 & 2 & 2 & 5 & 2 & 3 \\
\hline
\end{tabular}

afull controlled by insecticide from planting time to harvest ${ }^{\text {b}}$ controlled by insecticide until 45 dap

cHighly resistant, ${ }^{\text {Resistant, }}$ 'Moderately Resistant, 'Susceptible, 9Highly Susceptible

Sulistyowati (2012) reported that soybean trichome (length and density) will prevent the movement of stylet on the pod wall. Based on a research in Brazil by Souza et al. (2014), the IAC 17 and PI 227687 showed morphological resistance to pod sucking bug $N$. viridula through their high trichome density. Thus, it is suggested that morphological characteristics could be used as important indicator in the soybean resistance to pod sucking bug, and also used as selection indices in the soybean breeding program.

The resistance criteria to pod feeders based on pod damage are presented on Table 3, whereas Table 4 showed the resistance criteria based on seed damage. The classification of pod-sucking resistance based on the intensity of pod damage showed that there was no highly resistant genotype, but only one was classified as resistant (Table 5). In the ISP, two genotypes were identified as very resistant and resistant, respectively. When we observed based on the intensity of seed damage, there was no highly resistant genotype in both of IFP and ISP environments. In the IFP, one soybean genotype was classified as resistant, while in ISP there were four genotypes were resistant to pod sucking pests (Table 6). Based on seed damage as well as pod damage, most of genotypes were in moderate resistance to pest-sucking pests. There was a single genotype of soybean (NSP-16-2-8) which showed consistently resistant based on the pod damage as well as seed damage.

The grouping of soybean resistance to pod borer based on the intensity of pod damage, one resistant genotype was found in IFP, whereas in the ISP obtained one highly resistant genotype and one resistant genotype (Table 5). Based on the intensity of seed damage, a genotype was classified as resistant in the IFP, while in the ISP was obtained one very resistant genotype and four resistant genotypes (Table 6). There was no consistently resistant genotype in both of IFP and ISP environments. NSP-16-1-4 showed consistently resistant reaction based on the intensity of pod and seed damage only in the ISP environment.

The main difference between the pests of $R$. linearis and E. zinckenella in damaging the soybean pod is in the mouth type. In the case of this study, morphological characters of pods might become the resistance determinant to pod sucking bugs, while the resistance determinant to pod borer was due to morphological factor in pod wall and antibiosis resistance in soybean seed. Other study, for example by Dzemo et al. (2010) which evaluated the resistance of three cowpea varieties to pod sucking bug C. tomentosicollis, found differences between varieties in terms of pre-oviposition period, ovopoTable 6. The mapping of soybean resistance to pod feeding insects based on seed damage

\begin{tabular}{lcccccc}
\hline Criteria & \multicolumn{5}{c}{ Number of genotypes } \\
\cline { 2 - 7 } & \multicolumn{2}{c}{$R$ linearis } & \multicolumn{2}{c}{ E. zinckenella } & H. armigera \\
\cline { 2 - 7 } & IFPa & ISPb & IFPa & ISPb & IFPa & ISP b \\
\hline $\mathrm{HR}^{\mathrm{c}}$ & 0 & 1 & 0 & 0 & 0 & 0 \\
$\mathrm{R}^{\mathrm{d}}$ & 1 & 4 & 3 & 4 & 9 & 19 \\
$\mathrm{MR}^{\mathrm{e}}$ & 13 & 5 & 10 & 9 & 7 & 3 \\
$\mathrm{~S}^{f}$ & 8 & 10 & 7 & 6 & 3 & 0 \\
$\mathrm{HS}^{\mathrm{g}}$ & 2 & 4 & 4 & 5 & 5 & 2 \\
\hline
\end{tabular}

afull controlled by insecticide from planting time to harvest ${ }^{b}$ controlled by insecticide until 45 dap

cHighly resistant, ${ }^{\text {Resistant, }}$ 'Moderately Resistant, 'Susceptible, 9Highly Susceptible 
Table 7. Days to maturity and seed size of 24 soybean genotypes at full controlled environment (IFP) and controlled environment until 45 dap (ISP)

\begin{tabular}{|c|c|c|c|c|c|c|c|}
\hline \multirow[t]{2}{*}{ No } & \multirow[t]{2}{*}{ Genotype } & \multicolumn{3}{|c|}{$\begin{array}{l}\text { Days to maturity } \\
\text { (days) }\end{array}$} & \multicolumn{3}{|c|}{$\begin{array}{l}100 \text { seed weight } \\
\text { (g) }\end{array}$} \\
\hline & & IFPa & $I S P^{b}$ & $\operatorname{Avg}^{c}$ & IFPa & $\mathrm{ISP}^{\mathrm{b}}$ & $\mathrm{Avg}^{\mathrm{c}}$ \\
\hline 1 & NSP-16-2-13 & 77 & 81 & 79 & 15.30 & 16.02 & 15.66 \\
\hline 2 & NSP-16-1-1 & 81 & 85 & 83 & 13.55 & 13.06 & 13.30 \\
\hline 3 & NSP-16-30-7 & 78 & 83 & 80 & 14.73 & 14.19 & 14.46 \\
\hline 4 & NSP-16-4-4 & 83 & 87 & 85 & 14.45 & 12.96 & 13.71 \\
\hline 5 & NSP-16-16-2 & 83 & 84 & 84 & 15.32 & 13.71 & 14.51 \\
\hline 6 & NSP-16-3-3 & 78 & 79 & 79 & 14.71 & 14.92 & 14.81 \\
\hline 7 & NSP-16-6-13 & 78 & 80 & 79 & 15.48 & 15.07 & 15.28 \\
\hline 8 & NSP-16-1-2 & 80 & 82 & 81 & 15.53 & 15.09 & 15.31 \\
\hline 9 & NSP-16-5-5 & 84 & 87 & 85 & 14.83 & 13.87 & 14.35 \\
\hline 10 & NSP-16-6-11 & 79 & 79 & 79 & 15.86 & 16.40 & 16.13 \\
\hline 11 & NSP-16-8-1 & 79 & 82 & 81 & 13.74 & 14.31 & 14.03 \\
\hline 12 & NSP-16-1-3 & 81 & 82 & 82 & 14.63 & 13.81 & 14.22 \\
\hline 13 & NSP-16-6-12 & 83 & 83 & 83 & 14.56 & 14.28 & 14.42 \\
\hline 14 & NSP-16-6-8 & 80 & 80 & 80 & 14.01 & 13.53 & 13.77 \\
\hline 15 & NSP-16-2-8 & 78 & 77 & 78 & 15.36 & 15.77 & 15.57 \\
\hline 16 & NSP-16-12-15 & 79 & 81 & 80 & 15.92 & 16.12 & 16.02 \\
\hline 17 & NSP-16-6-3 & 81 & 80 & 81 & 14.83 & 15.00 & 14.91 \\
\hline 18 & NSP-16-19-7 & 83 & 82 & 83 & 13.93 & 14.90 & 14.42 \\
\hline 19 & NSP-16-1-7 & 79 & 81 & 80 & 14.32 & 14.19 & 14.25 \\
\hline 20 & NSP-16-6-7 & 78 & 78 & 78 & 15.65 & 14.05 & 14.85 \\
\hline 21 & NSP-16-1-4 & 79 & 80 & 79 & 13.65 & 13.94 & 13.79 \\
\hline 22 & Grobogan & 77 & 79 & 78 & 18.24 & 20.32 & 19.28 \\
\hline 23 & Anjasmoro & 85 & 85 & 85 & 14.65 & 14.53 & 14.59 \\
\hline \multirow[t]{2}{*}{24} & Argomulyo & 77 & 78 & 78 & 14.54 & 15.60 & 15.07 \\
\hline & Average & 80 & 81 & 81 & 14.91 & 14.82 & 14.86 \\
\hline
\end{tabular}

afull controlled by insecticide from planting time to harvest

${ }^{b}$ controlled by insecticide until 45 dap

caverage damage intensity of IFP and ISP

sition period and number of eggs. Furthermore, De Souza et al. (2014) reported that the resistance of soybean AC 100 and IAC to seed sucking E. heros was caused by non-preference resistance. Moreover, Krisnawati et al. (2016) stated that morphological pod characters such as number of pod/plants, number of seed/plants, and seed weight may not contribute to the soybean resistance to pod sucking bug. However, soybean resistance to pod sucking bug may exhibit antibiosis, and or antixenosis resistance.
The characteristics of tropical climate in Indonesia provide not only an ideal condition for the development and growth of pest complexes but also establish the user preferences for soybean varieties, i.e. early days to maturity ( $<80$ days) and large seed size (>14 g/100 seeds). The average of days to maturity in the IFP was 80 days (range of $77-84$ days) and ISP was 81 days (range of $77-87$ days). The seed size in IFP ranged from $13.55-18.14$ $\mathrm{g} / 100$ seeds (an average of $14.91 \mathrm{~g} / 100$ seeds) and in ISP ranged from $12.96-20.32 \mathrm{~g} / 100$ seeds (an average of $14.82 \mathrm{~g} / 100$ seeds) (Table 7). The days to maturity as well as the seed size seem not to be affected by the environments used in this study.

The NSP-16-2-8 was identified as resistant to pod sucking pest. This genotype has average days to maturity of 78 days and average seed size of $15.57 \mathrm{~g} / 100$ seeds. Soybean genotype NSP-16-1-4 categorized as resistant to pod borer showed average days to maturity of 79 days and average seed size of $13.79 \mathrm{~g} / 100$ seeds. According to the aspect of days to maturity, both soybean genotypes are in accordance with the preferences of soybean users in Indonesia, but for seed size, it was only NSP-16-2-8 suiting user' preferences in Indonesia.

Two genotypes which were resistant to pod sucking bug (NSP-16-2-8) and pod borer (NSP-16-1-4) were important for soybean development in the tropical area of Indonesia as well as for enhancing the soybean resistance to pod feeding insects. Resistant variety could act as direct control tactics in IPM programs. In IPM implementation, the resistant varieties are playing important roles. The advantages of using insect-resistant varieties are relatively applicable, compatible with other IPM component tactics, low cost, and environmentally friendly (Weeden et al., 2008). Even according to Teestes (1996), pest-resistant varieties have advantages on the economic aspect, ecological aspect, and safe for the environment. 


\section{CONCLUSION}

The yield losses due to pod sucking bug was higher than by pod borer and pod worm. There was no resistant genotype to the both of pod sucking and pod borer. The NSP-16-2-8 was resistant to pod sucking bug, while the NSP-16-1-4 was resistant to pod borer.

\section{ACKNOWLEDGMENT}

The authors would like to express gratitude to the Indonesian Agency for Agricultural Research and Development (IAARD), Ministry of Agriculture that have supported this research.

\section{REFERENCES}

Acle, D., \& Rolim, R.B. (1994). Infestation of soybean with two species of pod-sucking bugs. Insect Science and Its Application, 15, 337-341.

Anshori, A., \& Prasetiono, C. (2016). Pestisida pada budidaya kedelai di Kapupaten Bantul, Daerah Istimewa Yogyakarta. Caraka Tani, Journal of Sustainable Agriculture, 31 (1), 38-44.

Asadi, Purwantoro, A., \& Yakub, S. (2012). Genetic control of soybean resistance to soybean pod sucker (Riptortus linearis L.). Agrivita, 34(1), 28-35.

Asadi. (2009). Resistance identification of soybean germplasm to pod sucking bug. Buletin Plasma Nutfah, 15(1), 27-31.

Bae, S.D., Kim, H.J., \& Mainali, B.P. (2014). Infestation of Riptortus pedestris (Fabricius) decreases the nutritional quality and germination potential of soybean seeds. Journal of Asia-Pacific Entomology, 17, 477-481.

Baur, M.E., Boethel, D.J., Boyd, M.L., Bowers, G.R., Way, M.O., \& Heatherly, L.G. (2000). Arthropod populations in early soybean production systems in the mid-south. Environmental Entomology, 29, 312-328.

Bayu, M.S.Y.I. (2015). Attack level of various pod pests on soybean germplasm. Prosiding Seminar Nasional Masyarakat Biodiversitas Indonesia 1, p. 878-883.

Bundy, C.S., \& Mcpherson, R.M. (2000). Dynamics and seasonal abundance of stink bugs (Heteroptera: Pentatomidae) in a cotton-soybean ecosystem. Journal of Economic Entomology, 93, 697-706.

Chiang, H.S., \& Talekar, N.S. (1980). Identification of sources of resistance to the bean fly and two other agromyzidflies in soybean and mungbean. Journal of Economic Entomology, 73, 197-199.

Dabire-Binso, C.L., Malick, N., Sanon, A., Drabo, I., \& Foua, K. (2010). Resistance mechanism to the pod sucking bug, Clavigralla 1 tomentosicollis STAL (Hemiptera: Coreidae) in the cowpea IT86D-716 variety. International Journal of Tropical Insect Science, 30(4), 192-199.
De Godoi, C.R.C., \& Pinheiro, J.B. (2009). Genetic parameters and selection strategies for soybean genotypes resistant to the stink bug-complex. Genetics and Molecular Biology, 32, 328-336.

De Souza, P.V., Machado, B.R., da Silva, D.C., Menezes, I.P.P., Araujo, M.S., \& de Jesus, F.G. (2014). Effect of resistance and trichome inducers on attraction of Euchistus heros to soybean. African Journal of Agricultural Research, 9, 889-894.

Dzemo, W.D., Niba, A.S., \& Asiwe, J. (2010). A comparative study of the bionomics of Clavigrallatomentosicollis Stäl (Hemiptera: Coreidae) on three varieties of cowpea (Vigna nguiculata (L.) Walp). African Journal of Agricultural Research, 5, 567-572.

Gazzoni, D.L. (1998). Efeito de populações de percevejos na produtividade, qualidade da semente e características agronômicas da soja. Pesq Agrop Brasilia, 33, 1229-1237.

Hendrival, Latifah, \& Alfiatun, N. (2013). Efficacy some botanical insecticide for controlling pest pod sucking in soybean field. Agrista, 17(1), 18-27.

Janz, N., \& Nylin, S. (1997). The role of female search behavior in determining host plant range in plant feeding insects: a test of the information processing hypothesis. Proceedings of Royal Society B: Biological Sciences, 264 (1382), 701-707.

Johnson, S. N., Karley, A. J., Gregory, P. J., \& Brennan, R. M. (2017). Editorial: Сrop Traits for Defense against Pests and Disease: Durability, Breakdown and Future Prospects. Frontiers in Plant Science, 8, 209. http://doi.org/10.3389/fpls.2017.00209

Jones, W.A., \& Sullivan, M.J. (1978). Susceptibility of certain soybean cultivars to damage by stink bugs. Journal of Economic Entomology, 71, 534-536.

Krisnawati, A., Bayu, M.S.Y.I., \& Adie, M.M. (2016). Identification of soybean resistance to pod sucking bug (Riptortus linearis F.) by no-choice test. Biosaintifika, 8(3), 406-413.

Lourencao, A.L., Вraga, N.R., Miranda, M.A.C., Pereira, V.G., \& Reco, P.C. (2002). Avaliação de danos de percevejos e de desfolhadores em genótipos de soja de ciclos precoce, semiprecoce e médio. Neotropical Entomology, 31, 623-630.

Lucini, T., Panizzi, A. R., \& Backus, E.A. (2016). Characterization of an EPG waveform library for redbanded stink bug, Piezodorus guildinii (Hemiptera: Pentatomidae), on soybean plants. Annals of Entomological Society of America, 109(2), 198-210. doi: http://dx.doi.org/10.1093/aesa/sav1156

Mudjiono, G. (1988). Reciprocal relationship of insects - host. Faculty of Agriculture. Brawijaya University. Malang. Indonesia.

Mustikarini, F., Retnaningsih, \& Simanjuntak, M. (2014). Kepuasan dan loyalitas petani padi terhadap pestisida. Jurnal IImu Keluarga dan Konsumen, 7 (2), 93-102.

Naito, A. (2008). Low cost technology for controlling soybean insect pest in Indonesia. Food and Fertilizer Technology Center for the Asian and Pacific Region. Availabe at http://www.fao. org/prods/gap/database/gap/files/1276_insect_control_soybean_indonesia.pdf (access 2 February 2016).

Oldeman, L.R. (1974). An agroclimatic classification for evaluation of cropping systems 1974 in Southeast Asia. In Report of the FAO/UNDP International expert consultation on the use of improved technology for food production in raifed areas of tropical Asia. Annex III, 1-18, FAO, Rome. 
Pinheiro, J.B., Vello, N.A., Rossetto, C.J., \& Zucchi, M.I. (2005). Potential of soybean genotypes as insect resistance sources. Crop Breeding and Applied Biotechnology, 5, 293-300.

Prayogo, P., \& Suharsono. (2005). The optimum control of soybean pod sucking bug (Riptortus linearis) by entomopathogenic fungus Verticillium lecanni. Jurnal Litbang Pertanian, 24(4), 123-130.

Pretty, J., \& Bharucha, Z.P. (2015). Integrated pest management for sustainable intensification of agriculture in Asia and Africa. Insects, 6, 152-182.

Rahayu, M., Bande, L.O.S., Hasan, A., Yuswana, A., \& Rinambo, F. (2018). Contribution of pod borer pests to soybean crop production (case in Pondidaha, Konawe District, Southeast Sulawesi). IOP Conf. Series: Earth and Environmental Science, 122, 1-5. doi:10.1088/1755-1315/122/1/012039

Rahman, M.M., \& Lim, U.T. (2017). Evaluation of mature soybean pods as a food source for two pod-sucking bugs, Riptortus pedestris (Hemiptera: Alydidae) and Halyomorpha halys (Hemiptera:Pentatomidae). PLOS ONE 12(4): e0176187. https://doi. org/10.1371/journal.pone.0176187

Shepard, R.W., \& Wagner, G.J. (2007). Phyllo-plane proteins: emerging defenses at the areal frontline? Trends in Plant Science, 12, 51-56.

Singh, S.R., \& Allen, D. (1980). Pests, disease, resistance and protection in cowpea. In: Summafield, R.J., Bunching, A.H. (eds) Advances in Legume Science, pp. 419-443.
Souza, E.S., Baldin, E.L.P., Silva, J.P.G.F., \& Lourencao, A.L. (2013). Feeding preference of Nezara viridula (Hemiptera: Pentatomidae) and attractiveness of soybean genotypes. Chilean Journal of Agriculture, 73, 351-357.

Suharsono, \& Sulistyowati, L. (2012). Expression of resistance of soybean to the pod sucking bug Riptortus linearis (Hemiptera: Coreidae). Agrivita 34(1), 55-59.

Sumartini, 2016. Biopesticide to control pests and diseases on legume and tuber crops. Iptek Tanaman Pangan, 11 (2), 159-166.

Teestes, G.L. (1996). Plant resistance to inscts: a fundamental component of IPM. Radeliffes IPM World Textbook. The Univ. of Minnesota.

Timbó, R.V., Hermes-Lima, M., Silva, L.P., Mehta, A., Moraes, M.C.B., \& Paula, D.P. (2014). Biochemical aspects of the soybean response to herbivory injury by the brown stink bug Euschistus heros (Hemiptera: Pentatomidae). PLoS ONE 9(10): e109735. https://doi.org/10.1371/journal.pone.0109735

Traw, B.M., \& Dawson, T.E. (2002). Reduced performance of two specialist herbivores (Lepidoptera: Pieridae, Coleoptera: Chrysomelidae) on new leaves of damaged black mustard plants. Environmental Entomology, 31(4), 714-722.

Weeden, C. R., Shelton, A. M., \& Hoffman, M. P. (2008). Biological control: a guide to natural enemies in North America. Retrieved May 22, 2008 from: http://www.nysaes.cornell.edu/ent/biocontrol/info/ipmstrat.html 